Pamiętnik Literacki 2018, 3, s. 25-34

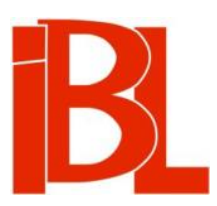

Katastrofizm okaleczający, Katastrofizm inspirujący? Awangarda a zagłada świata w “Nogach Izoldy Morgan" Brunona Jasieńskiego

Iwona Boruszkowska 
Pamiętnik Literacki CIX, 2018, z. 3, PL ISSN 0031-0514

DOI: $10.18318 / \mathrm{pl} .2018 .3 .2$

IWONA BORUSZKOWSKA Uniwersytet Jagielloński, Kraków

\title{
KATASTROFIZM OKALECZAJĄCY, KATASTROFIZM INSPIRUJĄCY? AWANGARDA A ZAGŁADA ŚWIATA W „NOGACH IZOLDY MORGAN” BRUNONA JASIEŃSKIEGO*
}

\author{
W moim początku jest mój kres. [...] \\ [ . . . . . . ......] \\ [...] U mego kresu mój początek ${ }^{1}$.
}

Polscy literaturoznawcy łączą tendencje katastroficzne przede wszystkim $z$ rozwijającym się we wczesnym modernizmie (czyli na przełomie XIX i XX wieku) dekadentyzmem, za jego kontynuację uważając późniejsze przejawy katastrofizmu. O gwałtownej zagładzie cywilizacji i zmierzchu wszelkich wartości nie przestano myśleć również w okresie działalności polskich twórców awangardowych. W literaturze Dwudziestolecia międzywojennego najpierw, w latach dwudziestych XX wieku, dominował aspekt ,jasny”: nastrój radości i entuzjazm, ujawniający się także w pełnych ekspresji działaniach dadaistów i futurystów. Potem zaś, w latach trzydziestych ${ }^{2}$, na pierwszy plan wysunął się aspekt „ciemny”: artyści praktykowali poezję wizjonerską, katastroficzną i ekspresjonistyczną. Jednak wydaje się, że podział na „pogodnych" futurystów, aktywnych w latach dwudziestych, i „ponurych” przedstawicieli awangardy wileńskiej czy lubelskiej $z$ lat trzydziestych jest sztuczny. To tradycyjne przeciwstawianie optymizmu cywilizacyjnego i energii twórczej polskich futurystów (w Krakowie: Tytus Czyżewski, Bruno Jasieński, Stanisław Młodożeniec; w Warszawie: Aleksander Wat, Anatol Stern) i poetów Awangardy Krakowskiej (Tadeusz Peiper, Julian Przyboś, Jalu Kurek, Adam Ważyk, Jan Brzękowski), którzy pisali w latach dwudziestych, poetom lat trzydziestych, należącym do Drugiej Awangardy (Lublin: Józef Czechowicz; Wilno: Teodor Bujnicki, Czesław Miłosz), nie wytrzymuje próby czasu, gdy przyjrzymy się katastroficznemu w swej wymowie dziełu przedstawiciela futuryzmu polskiego - Brunona Jasieńskiego.

* Tekst powstał w ramach projektu Style zachowań awangardowych (program Sonata 10, $\mathrm{nr}$ rej. 2015/19/D/HS2/01003) finansowanego przez Narodowe Centrum Nauki.

1 Th. S. Eli ot, East Coker. W: W moim poczatku jest mój kres. Przekł., koment., przypisy A. Pom o r s ki. Warszawa 2007, s. 284-291.

2 Na świecie trwał w latach trzydziestych kryzys gospodarczy (pogarszające się sytuacje polityczna i ekonomiczna pociagnęły $z$ sobą strajki i manifestacje), a skrajnie nacjonalistyczne nastroje panowały w polityce niemieckiej - literatura zaś odpowiedziała na ten stan utworami katastroficznymi i nasilającym się pesymizmem. 


\section{Katastrofizm okaleczający, katastrofizm inspirujący?}

Odkąd w 1918 roku Oswald Spengler ${ }^{3}$ ujął w formie książki Zmierzch Zachodu. Zarys morfologii historii uniwersalnej (Der Untergang des Abendlandes. Umrisse einer Morphologie der Weltgeschichte) trwające od dziesiątków lat myślenie o kresie, koń$\mathrm{cu}$, zmierzchu, poglądy prezentowane w tej pracy stały się symbolem europejskiego katastrofizmu. Współtworzyły także oblicze polskiego dekadentyzmu. Krzysztof Kłosiński, pisząc o występowaniu dyskursu katastroficznego w polskiej literaturze, przytacza wypowiedzi (m.in. Romana Dyboskiego i Karola Ludwika Konińskiego) z prasy lat dwudziestych i trzydziestych, świadczące o wszechobecności pesymizmu, długim utrzymywaniu się dekadentyzmu i permanentnym kryzysie: „coraz liczniejsze [...] przepowiednie "dnia gniewu bożego" i wizje "Sądu Ostatecznego" nad naszą upadającą cywilizacją, różne "Apokalipsy dnia dzisiejszego"”; „świadomość kryzysu, nastrój katastrofy wyraża się nie tylko w wielu dziełach o "upadku cywilizacji zachodniej"" .

Groźba końca cywilizacji od zawsze zapładniała wyobraźnię artystów, również poetów i pisarzy, a wśród ich inspiracji wymienić można nie tylko Apokalipsę św. Jana, myśl Artura Schopenhauera czy Oswalda Spenglera, ale także rodzimą filozofię Floriana Znanieckiego (1882-1958), przedstawioną w dziele Upadek cywilizacji zachodniej. Szkic z pogranicza filozofii kultury i socjologii (1921), oraz wydarzenia pierwszej wojny światowej. Wiele różnych przyczyn spowodowało powstanie tego typu utworów literackich, a wręcz zaistnienie całego nurtu katastroficznej powieści popularnej ${ }^{5}$.

Do owego nurtu zalicza się powieść Jasieńskiego Nogi Izoldy Morgan ${ }^{6}$. Współczesny jej autorowi, jego biograf i zarazem kolega po piórze (wspólnie wydali tomik Ziemia na lewo), Stern, podaje: „W historii naszej literatury nazwisko Jasieńskiego jest trwale związane $z$ dziejami polskiego futuryzmu. Jest on jednym $z$ czołowych twórców tego kierunku"7. Przy czym za najbardziej chyba charakterystyczna cechę „Zuchwałego eksperymentu poetyckiego” tego polskiego futurysty można uznać bunt. Jego hasła - jak twierdzą wcześni interpretatorzy dzieł Jasieńskiego - głoszone były w imię sprawiedliwości społecznej (jak w poemacie Pieśń o głodzie), wymierzone przeciwko mieszczaństwu (Rzygajace posagi), wojnie (Marsz) czy w ogóle względem otaczającej rzeczywistości. Równie dobrze ostrze protestu skierować mógł poeta przeciwko jednemu $z$ futurystycznych fetyszy: przeciwko maszynie. Uczynił to właśnie w utworze Nogi Izoldy Morgan.

Jest to pierwsza powieść Jasieńskiego (czy raczej mikropowieść lub opowiada-

O. Spengler, Zmierzch Zachodu. Zarys morfologii historii uniwersalnej. Skrót dokonany przez H. W e r n era. Przeł., przedm. J. M a r z ę cki. Warszawa 2001. Pierwodruk oryginału: t. 1 (Wien 1918); t. 2 (München 1922).

4 Katastrofizm i awangarda. Red. T. Bujnicki, T. Kłak. Katowice 1979, s. 23.

5 Zob. K. Kło s ińs ka, Katastroficzna odmiana powieści popularnej. W zb.: jw.

6 Zob. B. Carpenter, The Poetic Avant-Garde in Poland: 1918-1939. Seattle 1983. Zob. też K. J aw o r s k i, Dandys. Stowo o Brunonie Jasieńskim. Warszawa 2009. - K. P a w li k o w s k a, J. S tępień, European Influences on the Polish Poetic and Visual Avant-Garde. W zb.: The European Avant-Garde: Text and Image. Ed. S. D a ly, M. In s in ga. Newcastle upon Tyne 2012.

7 A. Stern, Bruno Jasieński. Warszawa 1969, s. 27. 
nie). Ukazała się w 1923 roku we Lwowie, w okresie, gdy jej autor dokonywał krytycznej rewizji polskiego futuryzmu, która podsumował w takich słowach:

Futuryzm polski nauczył człowieka współczesnego widzieć w przedmiotowych formach cywilizacji piękno swego własnego wzbogaconego ciała. Uleczył go $z$ fetyszyzmu, jakim opanowana jest cała futuryzująca myśl współczesna ${ }^{8}$.

Powstanie tej powieści poprzedziło napisanie na początku lat dwudziestych kilku wierszy opiewających zgodnie z futurystycznymi hasłami: miasto, masę, maszynę (np. Śpiew maszynistów). Również niektóre wydarzenia historyczne mogły wpłynąć na pewne wątki utworu - mowa o wypadkach politycznych związanych ze strajkiem powszechnym robotników w Krakowie, jakie w szkicu autobiograficznym Jasieński przedstawił następująco:

Wstrząsem [...] było krwawe powstanie w 1923 roku. Zagarnięcie Krakowa przez uzbrojonych robotników, rozgromienie pułku ułanów wezwanych dla uśmierzenia powstańców, odmowa strzelania do robotników ze strony oddziałów piechoty, bratanie się żołnierzy z powstańcami [...]. Dwadzieścia cztery godziny przeżyte $\mathrm{w}$ mieście oczyszczonym $\mathrm{z}$ policji i wojska wstrząsnęły od podstaw moim nie przebudowanym jeszcze do końca światem ${ }^{9}$.

Właśnie rok 1923 badacze określaja jako moment „oddalania się poety od futuryzmu i przechodzenia ku stanowisku rewolucyjnego artysty [...]"10, czego literackim śladem mają być: Nogi Izoldy Morgan, artykuł ze „Zwrotnicy” - Futuryzm polski (bilans) i wiersz Do futurystów. Edward Balcerzan zaznacza, że wtedy właśnie „minął czas apoteozy futuryzmu. Teraz chodzi o to, aby go unicestwić” ${ }^{11}$, amerykańska badaczka Nina Kolesnikoff twierdzi zaś nawet, iż Nogi Izoldy Morgan odzwierciedlają odrzucenie futuryzmu przez Jasieńskiego:

[...] Nogi Izoldy Morgan były ważnym dziełem w karierze literackiej Jasieńskiego. Powieść ta odzwierciedlała jego kategoryczne zerwanie z futuryzmem. Sygnalizowała dezaprobate autora dla futurystycznego kultu technologii, pokazując, jak materialistyczny świat rozpada się pod wpływem przewrotowych idei lub zdarzeń. Inżynier Berg jest początkowo oddanym wielbicielem maszyny, ale w końcu zaczyna się jej bać. Kult maszyny prowadzi do szaleństwa ${ }^{12}$.

Rzeczywiście, utwór Jasieńskiego można odczytywać jako zerwanie, ale przede wszystkim $z$ tradycyjną formą powieści, co też autor zaznacza we wstępie do tego krótkiego tekstu:

Tasiemce powieściowe, urągające zasadom elementarnej konstrukcji, należą już, miejmy nadzieję, do bezpowrotnej przeszłości.

Powieść dziś musi przestać już być opowiadaniem o pewnych faktach wywołujących dopiero w następstwie u czytelnika pewne stany psychiczne, odpowiadające tym faktom. Droga ta jest $\mathrm{z}$ gruntu fałszywa i celowa tylko w stosunku do czytelników o bardzo prymitywnej organizacji wewnętrznej. c erzan. Wrocław 1972, s. 237. BN I 211.

E. B a l c e r z a n, „Nogi Izoldy Morgan” Brunona Jasieńskiego. W zb.: Nowela, opowiadanie, gawęda. Interpretacje małych form narracyjnych. Red. K. Bartoszyński, M. Ja sińska-Wojtkowska, S. Sawicki. Warszawa 1974, s. 234.

12 N. Kole snik off, Bruno Jasieński. His Evolution from Futurism to Socialist Realism. Waterloo, Ont., 1982, s. 85. Podkreśl. I. B. 
Powieść współczesna poddaje konsumentowi pewne zasadnicze stany p sy chiczne, na podstawie których czytelnik konstruuje sobie szereg odpowiadających tym stanom faktów. Dlatego fabuła dla każdego czytelnika może się tu ułożyć inaczej i na tym polega jej niewyczerpane bogactwo ${ }^{13}$.

Treść utworu jest nader prosta: w wyniku wypadku tramwaj linii 18 odcina Izoldzie nogi, a jej narzeczony - inżynier elektrowni miejskiej - Witold Berg zabiera je do domu, gdyż są mu bliższe niż korpus kobiety:

Cała jego bolesna miłość do Izoldy skoncentrowała się teraz na jej nogach. Godzinami leżał na kozetce, przytulony wargami do miękkiej, pachnącej skóry zaróżowionych ud, jak dawniej, kiedy pieścił je, gdy były jeszcze własnością tamtej. [N 23] ${ }^{14}$

Futurystyczną świadomość Jasieńskiego przesyca refleksja o kresie, zmierzchu. Powieść kończy się zagładą kondycji ludzkiej, fantastyczną wizją ucieczki głównego bohatera przed pędzącym tramwajem numer 18 (dynamicznym elementem miasta, który uśmiercił Izoldę). Zapowiadane zaś we wstępie „stany psychiczne” to przede wszystkim lęki współczesnego człowieka, związane z poczuciem zagrożenia, jakie wywołuje niekontrolowany rozwój cywilizacji, w której maszyna jest symbolem „destruktywnego i upokarzającego fizykalizmu nowoczesności” ${ }^{15}$. Jasieński w artykule o futuryzmie tak określił wymowę swojego utworu: „W Nogach Izoldy Morgan przedstawiłem ten proces zakażenia psychiki współczesnej przez maszynę"16. Rozwój techniki, przemysłu (symptomy nowoczesności) oraz wzrost znaczenia maszyn powodowały zmiany w ludzkiej konstrukcji wewnętrznej, miały także wpływ na modyfikację estetyki i tematyki dzieł artystycznych. W innym tekście Jasieński używa bardzo obrazowego porównania, nazywając futurystyczne uwielbienie wytworów techniki „bakcylem nowoczesności”. Traktuje zatem te założenia odmiennie niż Filippo Marinetti ${ }^{17}$ czy rosyjscy futuryści (Władimir Majakowski albo Dawid Burluk) - „przez pojęcie futuryzmu [...] rozumiał [...] pewien stan świadomości, który odpowiada procesowi przezwyciężenia maszyny" ${ }^{18}$. Co prawda, autor Nóg Izoldy Morgan nie odrzucił maszyn jako elementu nowej estetyki, ale odsłonił grożące $\mathrm{z}$ ich strony niebezpieczeństwo.

W swojej interpretacji powieści Marian Stępień stwierdza, iż związek z maszyną: „czyni go [tj. Berga] nieszczęśliwym, obłąkanym, bezradnie uwikłanym w chaosie wielkiego miasta” ${ }^{19}$. Urządzenia mechaniczne, pojazdy - tramwaje, stanowią zagro-

B. J a s i eń s k i, Exposé [do „Nóg Izoldy Morgan”]. W: Utwory poetyckie, manifesty, szkice, s. 221222. Podkreśl. I. B.

Skrótem N odsyłam do książki B. J a si eń s ki e go Nogi Izoldy Morgan i inne utwory (Wybór, wstęp G. La s o ta. Warszawa 1966). Liczby po skrócie wskazują stronice.

B. Ols e n, W obronie rzeczy. Archeologia i ontologia przedmiotów. Przeł. B. Sh allc r o s s. Warszawa 2013, s. 149.

Ja sień ski, Futuryzm polski (bilans), s. 225. Główny temat tego artykułu stanowi w zasadzie stosunek człowieka do maszyny. Jasieński dokonuje porównania tej relacji w futuryzmie włoskim, rosyjskim i polskim. Zob. St ę pień, op. cit., s. 11-13.

Włoscy futuryści głosili afirmację wytworów techniki, a w identyfikacji człowieka z maszyną i w koncepcji człowieka zwielokrotnionego (uomo moltiplicato) widzieli możliwość wykreowania nowego wzorca antropologicznego.

St ę p i eń, Bruno Jasieński, s. 13.

Ibidem, s. 11. 
żenie, są animizowane i obdarzone zdolnością wyrządzania krzywdy człowiekowi niczym potwory czyhające na jego życie. Dlatego Berg tak przemawia do robotnika:

Duszą maszyny jest pęd, perpetuum mobile. Jedynym zaś powietrzem, jakim my możemy oddychać, jest właśnie ograniczoność. Konsekwencje są jasne. Zaszczepiliśmy sobie śmiertelną szczepionkę, która nas powoli całych opanowuje. [N 31]

Futurysta, który niegdyś wskazywał trzy fundamentalne komponenty nowoczesności: maszynę, demokrację i masę (tłum) ${ }^{20}$, teraz $\mathrm{w}$ pierwszym $\mathrm{z}$ nich widzi zagrożenie, zapowiedź zagłady świata i nawołuje do usunięcia tego elementu, do zniszczenia go, co łączy się z katastroficznym poglądem na cywilizację:

Zbliżamy się do końca z matematyczną dokładnością. Wkrótce wszystko dookoła nas zastapią maszyny. Będziemy się poruszali wśród maszyn. Każdy nasz ruch czynimy zależnym od maszyny. Oddajemy broń. Zdajemy się zupełnie w ręce obcego, wrogiego nam żywiołu. Obręcz żelaznego wysiłku nerwów, która utrzymuje jeszcze nad nimi naszą hegemonię, musi lada chwila pęknąć. Wtedy pozostaje walka albo obłęd. Na razie nikt tego nie widzi, nie rozumie. Jesteśmy zaślepieni swoją mocą. Wyjścia nie ma. Osaczyliśmy się ze wszystkich stron sami. I zresztą to już jest w nas. Wy bez maszyny żyć już nie potraficie. Przodkowie wasi może by jeszcze potrafili. Wy już nie. Bronić się nie można. Trzeba czekać. Trucizna jest w nas samych. Zatruliśmy się własną mocą. Lues ${ }^{21}$ cywilizacji. [N 31-32]

Istnienie maszyn, korzystanie $z$ wynalazków i nowinek technologicznych w codziennym życiu, opiewanie przez futurystów cywilizacyjnego pędu i cudów techniki Jasieński uważał za oczywiste, jednak podświadomy lęk przed maszynami (znakiem zbyt gwałtownych zmian) nakazywał mu ostrożność i ostrzeganie przed ewentualnością przejęcia przez nie władzy nad światem. Wydaje się, że Jasieński z dystansem podchodził do deklaracji futurystów włoskich, którzy głosili, jak Marinetti (w roku 1919): „Goraco kawałka żelaza [...] roznamiętnia nas”22, czy jak Enrico Prampolini (w roku 1922): „Odczuwamy jak maszyny”23. Maszyna nie mogła być już celem i idealnym wytworem aktywności cywilizacyjnej człowieka, a jedynie stanowić „Lues cywilizacji”. W powieści Jasieński dokonał tekstualizacji nastrojów społecznych panujących w jego epoce: strachu, poczucia wyobcowania nowoczesnego podmiotu czy przerażenia spowodowanych dominacją i powszechna gloryfikacją technologii. Wyjściem $z$ tej sytuacji było uczynienie $z$ maszyny wroga, skupienie na niej uwagi, podporządkowanie jej człowiekowi. O takim zadaniu mówi robotnik, kiedy odpowiada inżynierowi Bergowi:

Słyszałem was na sądzie - mówi jasnym, okrągłym głosem. - Nie wszystko tam zrozumiałem, ale mówiliście, że nadchodzi czas, że maszyny będą nami rządzić, a nie my nimi. A widzicie, jeden nasz ruch i wszystko stoi. I cisza taka, jak przed stworzeniem świata. Cóż wy teraz? [N 31]

Nogi Izoldy Morgan ukazują katastrofę, jednak nie tę z odległej przyszłości,

Zob. Nuż $w$ bżuhu. W zb.: Antologia polskiego futuryzmu i nowej sztuki. Wstęp, koment. oprac. Z. J a ro siński. Wybór, przygot. tekstów H. Zaworska. Wrocław 1978, s. 30. BN I 230. M. St ę p i en, Od anarchizmu futurysty do rewolucji społecznej - Bruno Jasieński. W zb.: Prozaicy Dwudziestolecia międzywojennego. Sylwetki. Red. B. F a ro n. Warszawa 1974, s. 277.

21 Lues - kiła, syfilis.

22 F. T. Marinetti, Les Mots en liberté futuristes. Milano 1919, s. 20. Cyt. za: T. Pe i pe r, Pisma wybrane. Oprac. S. J a w or s ki. Wrocław 1979, s. 108. BN I 235.

23 Cyt. za: Ch. Ba u m garth, Futuryzm. Przeł. J. Ta sar ski. Warszawa 1978, s. 341. 
z gatunku science fiction (jak w podobnym pod względem fabularnym Buncie w krainie maszyn Michała Rusinka z 1928 roku czy w cyklu fotomontaży zbliżonym w pesymistycznej wymowie: Miasto mtyn życia Kazimierza Podsadeckiego z 1929 roku i Narodziny robota Janusza Marii Brzeskiego z 1934 roku). Utwór Jasieńskiego to raczej pewnego rodzaju inwariant powieści katastroficznej, mówiącej o niedalekiej przyszłości czy wręcz o teraźniejszości autora, w której nieubłaganie nadchodzi koniec. Przywołany już Balcerzan zauważa: „Życiu człowieka zagrażają maszyny. Zbliża się czas, kiedy maszyna - żarłoczna, złowroga, rozumna - zapanuje nad ludzkością. I będzie chciała ją zniszczyć”"24.

Dowartościowanie maszyn w literaturze futuryzmu, nadanie im roli ikony nowoczesności doprowadziło do ich specyficznej ,antropomorfizacji”, przy jednoczesnym uprzedmiotowieniu człowieka i odebraniu mu władzy nad nimi:

Maszyny nie są tylko biernymi „sprawcami” wypadków, zbuntowane tramwaje gonią za swoimi ofiarami, przepełnione czymś, co nie tylko ożywiło ich żelazne cielska, ale upodobniło je do ludzi ${ }^{25}$.

Postępująca maszynizacja i industrializacja wywołują egzystencjalną niewiadomą, budzą lęk i prowadzą bohatera do szaleństwa. Berg traci kontakt z rzeczywistościa - nie wiemy, co jest prawdą, a co wytworem jego chorej imaginacji. Ponadto inżynier formułuje paranoiczne podejrzenia względem maszyn, widzi w nich zagrożenie, obawia się rewolty rzeczy:

Wróg jest inny, bliższy, z którym robotnik styka się codziennie, przy pracy, który niepostrzeżenie pochłania jego siły, zdrowie, a niekiedy i życie. Wrogiem tym jest maszyna [...].

Należy zniszczyć maszynę, zniszczyć natychmiast, jeżeli nie chcemy, aby ona nas zniszczyła. [N 30]

Berg próbuje uwolnić ludzkość od maszyny, dokonuje więc zamachu - usiłuje zniszczyć urządzenia w elektrowni, jednak zostaje złapany. Broniąc się w sądzie, ukazuje maszynę jako narzędzie wyzysku, nie jako pomoc, lecz jako rzecz wymykającą się ludziom spod kontroli i im zagrażająca. Chciałby obalić futurystyczną wizję świata, w którym ośrodkiem zainteresowania i elementem jak magnes ściagającym nadzieje człowieka stała się maszyna (jako aksjomat, symbol jedynej prawdziwej nowoczesności). Dlatego autor hiperbolizuje zagrożenie techniczne, przedstawiając maszyny niczym ożywione przedmioty czyhające na człowieka; już nie narzędzia podporządkowane ludzkiej pracy, ale zbuntowane i wyzwolone spod człowieczego ucisku.

\section{Dadamontaż albo strategia (de)montażu człowieka}

Fantastyczny wątek nóg żyjących bez reszty ciała, traktowanych przez Berga jako odrębna (dosłownie) całość, nasuwa skojarzania $z$ dadaistyczną techniką kolażu czy fotomontażu, która „zmieniła sposób spojrzenia na ludzkie ciało jako pewną

25 J. B e c z e k, Osoby i rzeczy. O metamorficznym statusie podmiotu w wybranych utworach Brunona Jasieńskiego i Andrzeja Trzebińskiego. W zb.: Podmiot i tekst $w$ literaturze XX wieku. Warsztaty interpretacyjne. Red. H. Gosk, A. Zi eniewicz. Przy współpr. K. Krowirandy, Ż. Nalew a j k. Warszawa 2006, s. 22. 
ustaloną całość, proponując w jego miejsce kreowany konglomerat ludzkiej natury i obcych elementów"26. Nowy człowiek dadaistów był okaleczonym korpusem, często $\mathrm{z}$ dodatkiem elementów symbolizujących rozwój technologiczny, niekiedy stawał się człowiekiem-maszyną. Pozostawiona w szpitalu Izolda to tylko „bezkształtny kadłub, ohydny i tragiczny” (N 23), pewnego rodzaju umaszynowiona postać, musi ona bowiem funkcjonować bez kończyn, które $z$ kolei otrzymują status odrębnego bohatera (odcięte od reszty korpusu nogi - jako pars pro toto - można traktować synekdochalnie). Obraz ten nie przedstawia prostej hybrydyczności i poczucia braku psychofizycznej jedności, ale coś więcej - metaforę całkowitej dezintegracji człowieka w świecie maszyn (czy też w świecie, w którym maszyna stanowi zagrożenie dla ludzkiej podmiotowości). Izolda bez nóg i nogi Izoldy, które nie ulegają rozkładowi - to dwa fragmenty człowieka-maszyny.

Powieść Jasieńskiego zawiera więc rozważania nad kondycją ówczesnej techniki i refleksje na temat jej rozwoju. Nowa technologia bierze w posiadanie człowieka - w przypadku Izoldy dokonała dezintegracji jej ciała, ostatecznie ja pochłaniajac:

Obejrzał się - tramwaj dotykał jego pleców. Na oświetlonej tarczy miał 18.

Mijały ich tramwaje. Na tylnym pomoście jednego Berg zobaczył opartą o poręcz Izoldę, która powiewała mu chustką. [N 35]

W dążeniu do stworzenia nowego człowieka wspierało futurystów rozumienie życia jako pędu, ciągłego ruchu, zmiany (silnie związanych z rozwojem technologicznym) ${ }^{27}$. Dynamizm i postęp konstruuja podmiotowość człowieka, wpychaja jednostkę w nowe role, wręcz zbliżają ją do bytu maszyny (która jest symbolem tego pędu) - stąd pokazanie pościgu tramwaju za Bergiem. Próbę ucieczki inżyniera przed pojazdem można interpretować jako dramatyczną walkę o własną tożsamość. W ruchu, będącym unikiem przed afirmowanymi przez futurystów wytworami cywilizacji, konstytuuje się nowy awangardowy podmiot dzieł Jasieńskiego - nastawiony krytycznie do wcześniej głoszonych haseł, świadomy niebezpieczeństwa (grożącego, gdy futurystyczny projekt umaszynowienia człowieka się nie powiedzie), przeczuwający katastrofę.

\section{Człowiek-maszyna. Zawsze fragment}

W futurystycznych działaniach strategią nadrzędna były przebudowa, przekształcenie, rewolucjonizowanie. Antytradycjonalizm futurystów dotyczył także kobiet. Jak deklarowali oni w tekście programowym Do narodu polskiego. Manifest $w$ sprawie natychmiastowej futuryzacji życia: „Rozróżniamy spomiędzy dzieł sztuki architektonicznej, plastycznej i technicznej - KOBIETE - jako doskonałą maszynę rozrod-

P. Strożek, Nic, to znaczy wszystko. Interpretacje niemieckiego dada. Warszawa 2016, s. 89. Autor tej pracy analizuje praktyki artystyczne berlińskich futurystów, którzy w swoich dziełach ukazywali okaleczone przez wojnę sylwetki, dodając do nich elementy będące fragmentami niecielesnymi, przedmiotami.

27 Zob. A. Zeidler-J a n is zew ska, Prędkość - film - media - śmierć. Od futurystycznej fantazji do estetyki znikania. W zb.: Prędkość i przyjemność. Kino i telewizja $w$ dobie symulacji elektronicznej. Red. A. Gwóźdź. Kielce 1994. - B. Sienkiewicz, Poznawanie i nazywanie. Refleksja cywilizacyjna i epistemologiczna $w$ polskiej poezji modernistycznej. Kraków 2007, s. 158. 
czą"28. Doświadczenie pierwszej wojny światowej, rewolucje i konflikty były tak traumatyczne, że niektórzy dotychczasowi zwolennicy szalonego postępu techniki przewartościowali swoje poglądy - intensyfikacja prędkości prowadzić może jedynie do katastrofy. Tę groteskowość apoteozowanego wcześniej pędu cywilizacji zauważyć można w opisach odnoszących się do odciętych nóg bohaterki powieści.

Dolne kończyny Izoldy Morgan, amputowane przez tramwaj numer 18, opisuje Jasieński w sposób następujący:

Były to nogi wyzywająco białe i przedziwnie długie. Zakończone maleńką, wąską, wysoko sklepioną stopa, dostatecznie wysmukłe w pęcinach, wybuchały w nieskazitelnie modelowane podudzie, bardzo wysokie, twarde i jędrne. Od drobnych maleńkich kolan udo białe, o aksamitnym połysku, pokryte było całe siecią ledwie dostrzegalnych niebieskich żyłek, nadających kobiecemu ciału powagę marmuru. Drobne stopy tonęy jeszcze w płytkich, lakierowanych pantofelkach, a czarne, jedwabne pończochy okalały je powyżej kolan, podobnie jak w momencie, kiedy jeszcze unosiły swą właścicielkę. [N 22-23]

Odcięte żyjące nogi - to groteskowa esencja kobiecego ciała, a zarazem symbol rozpadu czy też metamorficzności, jakie cechują podmiotowość nowoczesną (zdaniem Charlesa Taylora, cała sztuka XX wieku ukazuje ów rozpad ${ }^{29}$ ). Tramwaj przepoławia Izoldę, czyniąc $z$ jej nóg odrębny byt, dodatkowo zaś uprzedmiotowiając je (Berg traktuje je przedmiotowo, jak rzecz właśnie). Zatem w postaci Izoldy bohater futurystyczny przekracza swoja jednolita tożsamość, znika tradycyjny podmiot, otwiera się na „ruch odbywający się poza zasięgiem [...] władzy i wyobraźni” ${ }^{30}$, dokonuje się rozszczepienie człowieka, zmienia się jego perspektywa postrzegania rzeczywistości - odtąd będzie on widział już zawsze fragment: a więc „powrót do koncepcji człowieka postrzeganego holistycznie stracił rację bytu" ${ }^{31}$. Kobiece nogi nie są tylko fetyszem, obiektem uwielbienia Berga („Cała jego bolesna miłość do Izoldy skoncentrowała się teraz na jej nogach”), oddzielonym od samej bohaterki i autonomicznym:

Figura „samokroczących nóg Izoldy Morgan” staje się [...] metaforą zmieniającego się świata, w którym kolejne dziedziny życia człowieka uwalniają się spod naszej kontroli, poczynając egzystować podług własnych reguł i zasad ${ }^{32}$.

Kobiece nogi - rekwizyt erotyczny, potencjalny substytut pożądania Berga, oznaczający seksualność kobiety i jej uprzedmiotowienie, pełnią też funkcję symbolu zagłady świata, są figurą kryzysu ujętego we fragmencie (czyli melancholijnym przypomnieniu, że kiedyś istniała jakaś całość). Samobójcza śmierć bohaterki to protest przeciwko tej reifikacji i wołanie o ponowną integrację rozczłonkowanych

28

B. J a si eń ski, Do narodu polskiego. Manifest $w$ sprawie natychmiastowej futuryzacji życia. W: Utwory poetyckie, manifesty, szkice, s. 205. Człowiek (kobieta) widziany był przez futurystów jako idealny mechanizm.

Ch. Ta y l o r, Źródła podmiotowości. Narodziny tożsamości nowoczesnej. Przeł. M. G r u s z c zy ński [i in.]. Oprac. nauk. T. Gada cz. Wstęp A. Bielik-Robs on. Warszawa 2012.

Ibidem, s. 850.

B eczek, op. cit., s. 30.

M. Kar eński-Ts churl, Czy dlatego, że my się par example nie kochamy? O erotyce futurystycznej na przykładzie poezji Brunona Jasieńskiego i Anatola Sterna. „Teksty Drugie” 2000, nr 6, s. 61 . 
części ciała (nogi umierają wraz z Izolda) oraz duszy. Tytułowy fetysz stanowi tu jedna $z$ wielu cząstek rozszczepionego świata nowoczesnego. Demontaż podmiotowości dotyczy przecież też samego Berga, osuwającego się w obłęd, tracącego kontakt z realnością, rozczłonkowującego swoją świadomość, którego spoistość została bezpowrotnie zaprzepaszczona (bo taką cenę płaci się za futurystyczną fascynację pędem, techniką, rewolucją). Walka $z$ maszyną jest bowiem przegrana $z$ góry w sytuacji, którą u progu XX wieku Gerald Stanley Lee opisywał jako całkowita zależność od maszyny: „Wydaje się, że żadna rzecz [...] nie jest w naszej nowoczesnej epoce wolna od związków $z$ maszynerią. Wraz z losem maszyny owe rzeczy trwają lub upadają"33.

Nóg Izoldy Morgan Brunona Jasieńskiego nie uważa się może za najważniejsze dzieło pisarza czy za utwór najbardziej dlań charakterystyczny. Pozostaje on jednak świadectwem futurystycznego lęku przed maszyną (symbolem postępu), połączonego $z$ dadaistyczną ciekawością wszelkich nie-ludzkich bytów (np. ożywionych i zabójczych maszyn) i kryzysem estetyki futurystycznej. Jeżeli odrzucimy dość oczywiste drogi interpretacji utworu w kontekście awangardowej erotyki ${ }^{34}$ czy fetyszyzacji obiektu pragnienia ${ }^{35}$, pozostaje nam rozumienie owego dzieła jako futurystycznego manifestu o obawie przed zagładą świata, jako tekstu o odczłowieczeniu, deformacji i transformacji w istotę człekopodobną (o pozbawieniu podmiotowości), jako narracji o strachu przed niedostępnymi ludziom możliwościami maszyn (i o tym, że w konfrontacji $z$ wytworami swojego intelektu oraz w zderzeniu $z$ osiągnięciami techniki i rozwoju cywilizacji człowiek nie ma szans - jest bowiem śmiertelny).

Tekst Jasieńskiego wyraża kryzys nowoczesności w momencie przesilenia przypadający na Dwudziestolecie międzywojenne ${ }^{36}$, ale także stanowi „pożegnanie z futuryzmem”, odpowiedź na gwałtowne cywilizacyjne przemiany i rozpad wartości, „studium świadomości przeciążonej futurystyczną wyobraźnią" ${ }^{37}$. Należy odczytywać tę powieść nie tyle jako odrzucenie technicyzacji i industrializacji, ile jako zakwestionowanie bezrefleksyjnego uwielbienia maszyny, ukazanie ambiwalentnego stosunku do wytworów techniki, krytyczne do nich podejście oraz zapowiedź potencjalnego kryzysu. Bohaterowie utworu: Berg i Izolda, to dwie wersje apokaliptycznej podmiotowości, wchodzącej w kolizję z pędzącą ku przepaści cywilizacją. Katastrofa spełnia się w nich: w ich życiu, w otaczającym świecie czy na poziomie ich świadomości, więcej: to oni sami stają się jej emblematami - pofragmentowanymi (Izolda w sferze ciała, Berg - psychicznie), rozbitymi, zniszczonymi.

G. S. Le e, Głos maszyny. Wprowadzenie do XX wieku. Przeł. J. Li s z k ow s ka. W zb.: Umaszynowienie. Red. K. Hoffmann, J. Koszarska, P. Bogalecki. Szczecin 2009, s. 129.

Zob. Kareńs ki - Ts c hurl, op. cit., s. 61.

Zob. A. Alks ni n, „Nogi Izoldy Morgan”, czyli kobiety i tramwaje. „Ruch Literacki” 2013, z. 3.

Zob. A. Bi eli k-R ob s o n, Inna nowoczesność. Pytania o współczesna formułę duchowości. Kraków 2000. Zob. też rozważania P. Ri c o e u r a na temat kryzysu człowieka nowoczesnego (Kryzys - zjawisko swoiście nowoczesne. Przeł. J. Margańs ki. W zb.: O kryzysie. Rozmowy w Castel Gandolfo. T. 2. Przygot., przedm. K. Mi chals ki. Warszawa 1990, s. 36, 53-56).

B alc erzan, op. cit., s. 238. 


\author{
Abstract \\ IWONA BORUSZKOWSKA Jagiellonian University, Cracow \\ DAMAGING CATASTROPHISM, INSPIRING CATASTROPHISM? AVANT-GARDE AND WORLD \\ DESTRUCTION IN BRUNO JASIEŃSKI'S "NOGI IZOLDY MORGAN" (“THE LEGS OF \\ IZOLDA MORGAN")
}

The article contains considerations about the destructive tendencies that were developing in the Inter war period and having their origin e.g. in early modernism and decadence. It is also an attempt at verifying of the rigid division of the Inter war Years into bright and dark ones. The paper analyses Bruno Jasieński's text Nogi Izoldy Morgan (The Legs of Izolda Morgan) (1923), while the context for the novel is a critical revision of the Polish futurism included into Futuryzm polski (bilans) (Polish Futurism. Summary) (1926). Jasieński's futurist awareness is steeped in reflection about the end and twilight of civilisation, and the novel contains observations on the condition of the then technology and its development. The piece is a peculiar "farewell to futurism," an answer to the rapid changes in civilisation and fall of values, a challenge to gullible adoration of machine. 